\title{
The prevalence of hypertension and abnormal kidney function in children with sickle cell disease -a cross sectional review
}

Prasad Bodas ${ }^{1 *}$, Alex Huang ${ }^{2,3}$, Mary Ann O'Riordan ${ }^{2,3}$, John R Sedor ${ }^{4}$ and Katherine MacRae Dell ${ }^{2,3,4}$

\begin{abstract}
Background: Renal disease is a known contributor to mortality in adults with sickle cell disease (SCD) and renal abnormalities are evident in childhood. Hyperfiltration (evidenced by elevated glomerular filtration rate, GFR) occurs in children with SCD early in disease. However, the incidence of low GFR $(<90 \mathrm{ml} / \mathrm{min} / 1.73 \mathrm{~m} 2)$ suggestive of chronic kidney disease (CKD), is not well established. The prevalence of hypertension is also not well known. The goal of this study was to determine the prevalence of hypertension and CKD in a cohort of children with SCD.

Methods: We performed a retrospective chart review of patients followed at the Rainbow Babies and Children's Sickle Cell Disease Clinic who were seen during routine follow up visits. Inclusion criteria were all patients ages 3-18. Exclusion criteria included recent (within 2 weeks) hospitalization and/or episode of acute chest, pain crises, febrile illness or red blood cell transfusion. Data collected included serum creatinine, blood pressure and history of sickle cell complications (acute chest syndrome, stroke or stroke risk). Estimated GFR (eGFR) was calculated using the updated Schwartz creatinine-based estimating formula. Analysis examined the associations among eGFR, blood pressure and sickle cell complications. The Institutional Review Board at University Hospitals Case Medical Center approved this study.
\end{abstract}

Results: A total of 48 children had complete data available. Mean eGFR was $140 \mathrm{~mL} / \mathrm{min} / 1.73 \mathrm{~m}^{2}+/-34.9$ (range 71.9-404.2 mL/min/1.73 $\mathrm{m}^{2}$ ). Four patients (8.3\%) had eGFRs $<90 \mathrm{~mL} / \mathrm{min} / 1.73 \mathrm{~m}^{2}, 35$ patients (72.9\%) had eGFRs > $120 \mathrm{~mL} / \mathrm{min} / 1.73 \mathrm{~m}^{2}$ and 9 patients (18.8\%) had eGFRs in the normal range. Eight patients (16.7\%) had evidence of elevated blood pressures (pre-hypertension or hypertension). There was no correlation between eGFR and age, and no association of eGFR with acute chest or stroke risk.

Conclusion: In this SCD cohort, we identified abnormally low eGFR (suggestive of early CKD) in 8.3\% of patients and elevated blood pressure in $16.7 \%$. These findings are in contrast to other published studies that show primarily normal or elevated GFR and the absence of or minimal hypertension. These findings indicate that elevated blood pressure and decreased eGFR are not uncommon in children with SCD, and should be more rigorously studied.

Keywords: Sickle cell disease, Nephropathy, Chronic kidney disease, Hypertension

\footnotetext{
* Correspondence: PBodas@chmca.org

${ }^{1}$ Department of Pediatrics, Division of Hematology and Oncology, Akron

Children's Hospital, Akron, OH 44302, USA

Full list of author information is available at the end of the article
} 


\section{Background}

Chronic kidney disease (CKD) in patients with sickle cell disease (SCD) is a risk factor for early death. This mortality association is stronger than that of an episode of the acute chest syndrome, febrile episode with positive blood culture, acute stroke, right upper quadrant syndrome, or severe acute anemia [1]. Retrospective studies suggest that nephropathy of varying severity occurs in $5-18 \%$ of sickle cell patients, depending on the age studied [2-5], and up to one third of adults with SCD will develop CKD [1].

Renal consequences of SCD are evident in early life, and can involve multiple segments of the nephron. Impaired urine concentrating ability is almost universally present early in childhood. Hematuria and overt papillary necrosis can develop as a result of medullary ischemia [6-10]. Glomerular filtration rate (GFR) is elevated. Increased renal blood flow and subsequent glomerular hypertrophy are thought to contribute to the development of proteinuria and progressive glomerulosclerosis (sickle cell glomerulopathy). Renal complications may not become clinically overt until the second decade of life. However, up to $20 \%$ of young adults with SCD exhibit nephrotic range (heavy) proteinuria [11-13].

Because the survival rate of SCD patients is increasing, CKD will likely play a greater role in morbidity and mortality in the future. Characterizing the early kidney disease phenotype will be important in designing clinical trials. The goal of this study is to describe the prevalence of hypertension and abnormal renal function in a wellcharacterized group of children with SCD.

\section{Methods}

This study was approved by the Institutional Review Board at University Hospitals Case Medical Center.

We retrospectively reviewed records of children ages 3-18 years actively receiving care at the University Hospitals- Rainbow Babies and Children's Pediatric Sickle Cell Clinic between March 2010- January 2011. Data obtained from the most recent well outpatient visit included age, gender, height, blood pressure, and serum creatinine concentration. Blood pressure measurements reflect a single seated oscillometric measurement obtained during clinic vital sign assessments using a Dynamap device. The serum creatinine was the most recent one obtained during a routine outpatient visit. Because serum creatinine can be affected by hydration status and/or medication use (e.g. non-steroidal anti-inflammatory agents) in the context of an acute illness, the value utilized was one that was obtained at least 2 weeks after an acute illness.

Sickle cell genotype was identified from the patient record, determined by hemoglobin electrophoresis or high-performance liquid chromatography (HPLC). We also collected historical information regarding the occurrence of two severe sickle cell complications: (1) acute chest syndrome (ACS); and (2) stroke or high risk for stroke as identified by trans-cranial Doppler screening [14]. Patients who had received a blood transfusion or had known illness (including any sickle cell crisis) within two weeks prior to the visit were excluded, as were those for whom complete data were not available.

Renal function was assessed by determination of eGFRs calculated using the updated "bedside" Schwartz equation:

$$
\begin{aligned}
\operatorname{GFR}\left(\mathrm{mL} / \mathrm{min} / 1.73 \mathrm{~m}^{2}\right)= & {[0.413 \times \operatorname{Height}(\mathrm{cm})] } \\
& / \text { Serum creatinine }(\mathrm{mg} / \mathrm{dL})
\end{aligned}
$$

This formula, which utilizes standardized serum Isotope Dilution Mass Spectrophotometry (IDMS) traceable creatinine measurements has been validated in pediatric patients with and without CKD using measured glomerular filtration methodologies (iohexol clearance) [15-18]. All serum creatinine values used in this study were obtained using an IDMS-traceable serum creatinine assay. For blood pressure analysis, pre-hypertension (systolic BP in 90- $<95$ th\% for age, height, and gender) and hypertension (systolic BP $\geq 95$ th\% for age, height, and gender) were defined based on published normative data [19]. High stroke risk was defined as the history of a stroke and/or abnormal trans-cranial Doppler velocity screening.

\section{Statistical analysis}

Pearson correlation coefficients were used to determine the correlation between eGFR and age and systolic and diastolic blood pressure percentiles. The association between eGFR and the presence of clinical events including ACS, high stroke risk based on trans-cranial Doppler velocity screening, and genotype was determined using distributionally appropriate two-sample tests ( $t$ tests were used for normally distributed data and Wilcoxon rank sum tests were used for non-normally distributed data).

\section{Results}

Data from 48 patients were included in this analysis. Demographics, clinical characteristics, and measurements are shown in Table 1 . The majority of subjects (32/48) had $\mathrm{HbSS}$ disease, with the remainder having $\mathrm{HbS} / \mathrm{beta0}$-thalassemia (1/48), $\mathrm{HbS} / \mathrm{C}(9 / 48)$, or $\mathrm{HbS} /$ beta + thalassemia (6/48) genotype. Mean age was $12+/-3.1$ years (range 3-17 years) and $52 \%$ of subjects were male. A history of at least one episode of the acute chest syndrome was present in 19/48 (39.6\%) patients. None of the patients had stroke, but $6 / 48(12.5 \%)$ had high stroke risk noted by transcranial Doppler screening. 
Table 1 Demographic and clinical characteristics of study population

\begin{tabular}{ll}
\hline $\mathbf{n}$ & $\mathbf{4 8}$ \\
\hline Male: Female & $25: 23$ \\
Age, mean (range in years) & $12+/-3.1(3-17)$ \\
History of acute chest syndrome, $\mathrm{n}(\%)$ & $19(39.6)$ \\
Elevated stroke risk, $\mathrm{n}(\%)$ & $6(12.5)$ \\
Pre-hypertension, $\mathrm{n}(\%)$ & $4(8.3)$ \\
Hypertension, $\mathrm{n}(\%)$ & $4(8.3)$ \\
eGFR* mean (range) & $140+/-34.9$ (71.9-404.2) \\
eGFR* sugroups & \\
$<90$ & 4 \\
$90-120$ & 9 \\
$>120$ & 35 \\
Sickle cell genotype & \\
SS, $\mathrm{n}(\%)$ & $32(66.7)$ \\
SC, $\mathrm{n}(\%)$ & $9(18.8)$ \\
S beta +-thalassemia, $\mathrm{n}(\%)$ & $6(12.5)$ \\
S beta 0-thalassemia, $\mathrm{n}(\%)$ & $1(2.1)$ \\
\hline$*$
\end{tabular}

* eGFR expressed as $\mathrm{ml} / \mathrm{min} / 1.73 \mathrm{~m}^{2}$.

Mean eGFR was $140 \mathrm{~mL} / \mathrm{min} / 1.73 \mathrm{~m}^{2}+/-34.9$ (range 71.9- 404.2). Four patients (8.3\%) had eGFR below the normal range $(<90 \mathrm{~mL} / \mathrm{min} / 1.73 \mathrm{~m} 2)$, suggestive of CKD. Conversely, 35 patients (72.9\%) had eGFR above the normal range $(>120 \mathrm{~mL} / \mathrm{min} / 1.73 \mathrm{~m} 2)$. A total of 8 patients had elevated blood pressures. Pre-hypertension was present in $4 / 48(8.3 \%)$ and overt hypertension was present in $4 / 48(8.3 \%)$ of patients. The characteristics of the patients in the low eGFR, normal or elevated eGFR, elevated BP, and non-elevated BP are summarized in Table 2.

There was no significant correlation between eGFR and age or blood pressure. eGFR was not associated with gender, genotype, or the presence or absence of acute chest history or stroke risk.

\section{Discussion}

The results of this study demonstrate the presence of abnormal kidney function (eGFR $>120$ or $<90 \mathrm{ml} / \mathrm{min} /$ $1.73 \mathrm{~m} 2$ ) in a significant proportion of the study population. The majority of these (35/48) had elevated eGFR consistent with hyperfiltration. This finding is consistent with previous published reports in SCD. In contrast, low eGFR values $\left(<90 \mathrm{~mL} / \mathrm{min} / 1.73 \mathrm{~m}^{2}\right)$ were noted in $8.3 \%$ of our population, a cohort with a mean age of 12.5 years. This finding is contrary to some published reports which have suggested CKD is a later finding $[2,3]$. Of note, a more recent cross-sectional study by McPherson Yee, et al. [20] reported an $11.6 \%$ prevalence of eGFR $<90$ $\mathrm{mil} / \mathrm{min} / 1.73 \mathrm{~m} 2$ in their patient population (mean age $11.4+/-4.5$ years), supporting our finding that CKD may be more common in the pediatric population than previously recognized. In contrast to that study and other previously published reports [2-4], however, we found no correlation between age and eGFR. The differences between our findings and those of prior studies may be due to the relatively small sample size of our study, or the age distribution of our cohort, which had no adults and only one child over age 16 years.

Interestingly, in our analysis we were unable to show correlation of eGFR and episodes of the acute chest syndrome or high stroke risk. This could suggest that the factors contributing to the development of these complications may be different than those influencing the development of CKD. Alternatively, the absence of a correlation could have been related to the relatively small sample size and few clinical events. One factor that could uniquely contribute to the development of CKD is the presence of one or more APOL1 "risk variants," which has been shown to contribute to the development of non-diabetic CKD $[21,22]$. APOL1 genotyping was beyond the scope of this study but would be an important area of future investigation.

Taken together, our data and that of others suggest that abnormally low GFR is not an uncommon problem

Table 2 Characteristics of patients by eGFR and blood pressure

\begin{tabular}{|c|c|c|c|c|}
\hline & Low GFR (eGFR $<90 \mathrm{ml} / \mathrm{min} / 1.72 \mathrm{~m}^{2}$ ) & $\begin{array}{l}\text { Normal or } \\
\text { elevated eGFR }\end{array}$ & $\begin{array}{l}\text { Elevated BP (hypertension } \\
\text { or pre- hypertension) }\end{array}$ & Non-elevated BP \\
\hline n (\%) & 4/ $48(8.3 \%)$ & 44/ 48 (91.7\%) & $8 / 48(16.6 \%)$ & 40/48 (83.3\%) \\
\hline Male: Female & $2: 2$ & 23:21 & $3: 5$ & $22: 18$ \\
\hline Age, mean (range in years) & $12.5+/-2.1(10-15)$ & $12+/-3.2(3-17)$ & $10.5+/-2.4(6-13)$ & $12.3+/-3.2(3-17)$ \\
\hline \multicolumn{5}{|c|}{ Genotype, $n$ (\% of total patients) } \\
\hline SC & $2(4.2)$ & $30(62.5)$ & $6(12.5)$ & $26(54.2)$ \\
\hline SS & $1(2.1)$ & $8(16.6)$ & $1(2.1)$ & $8(16.7)$ \\
\hline S beta +- thalassemia & $1(2.1)$ & $5(10.4)$ & $1(2.1)$ & $5(10.4)$ \\
\hline S beta 0-thalassemia & $0(0)$ & $1(2.1)$ & $0(0)$ & $1(2.1)$ \\
\hline
\end{tabular}


for children with SCD, and renal function should be assessed routinely in these patients. However, determining the optimal method for assessing renal function in the clinical setting as well as frequency of monitoring can be problematic. Quantification of inulin clearance in a timed urine collection is considered the "gold standard" measurement of GFR. However, this method is technically demanding, requiring bladder catheterization and 24 hour urine collection [23,24]. Nuclear medicine based techniques such as iohexol or technetium ${ }^{99} \mathrm{~m}-$ labeled diethylenetriaminepentaacetic acid (DTPA) provide accurate results comparing favorably with inulin clearance and does not require timed urine collections [25-28]. However these procedures may not be available at all centers. Because these techniques are costly and time consuming, their feasibility for clinic-based screening of renal function is limited. Creatinine-based estimating formulas (such as the bedside Schwartz formula in children or the MDRD formula for adults) or 24 hour urine collections for creatinine clearance are less expensive and relatively easy to obtain but also have limitations. Importantly, increased creatinine secretion due to hyperfiltration or tubular dysfunction can result in overestimation of GFR.

Pediatric patients with SCD have typically been thought to have low normal blood pressures. In a study of 85 children, Aygun et al. [29] identified no hypertensive patients despite abnormal calculated and measured GFRs. In addition, in a Saudi Arabian cohort of 69 children with SCD aged 1-16 years old, blood pressure measurements were within normal range [30]. However, in the present study, $16.6 \%$ of patients had elevated blood pressures (overt hypertension in $8.3 \%$ and prehypertension in $8.3 \%$ ). Interestingly, the prevalence of pre-hypertension and hypertension in our cohort is not statistically different than what has been found in school based screenings of African American children in this country [31]. Of note, investigators in a recent study demonstrated a $10.3 \%$ prevalence of hypertension in a cohort of thirty-eight children with SCD, based on inclinic blood pressure screening [32]. Importantly, that study utilized ambulatory blood pressure monitoring (ABPM, the gold standard for diagnosing hypertension) to determine the true prevalence of hypertension and found $43.6 \%$ had ambulatory hypertension. This suggests that the incidence of "masked" hypertension may be quite high in pediatric SCD patients, with rates approaching those of children with clear evidence of CKD [33]. These findings coupled with our data suggest that hypertension may be under diagnosed in children with SCD when using standard clinic based assessments. This highlights the need for identification and evaluation of elevated blood pressures in the clinic setting using standardized, validated methods.
Although rates of hypertension are high in patients with CKD, we were unable to demonstrate a correlation between eGFR and systolic or diastolic hypertension in our population. This lack of correlation may have been due to the relatively small number of patients with CKD. However, it does suggest that hypertension is present in this population in the absence of clear evidence of renal dysfunction.

Our study had several important limitations. These included a relatively small sample size, and the retrospective design. Utilization of data obtained during routine clinical practice and abstracted from retrospective chart review imposed significant constraints. Blood pressure measurements recorded at each visit were collected according to the standard clinical practice, and not in accordance with approved methodology [19]. Because repeated measures were not performed and/or hypertension was not confirmed with manual readings, it is possible that the prevalence of true hypertension may be lower than our data suggest. In addition, as discussed above, creatinine-based eGFRs, which were utilized in the present study, have important limitations.

One important additional limitation is the absence of data on albumin excretion. Albuminuria has been shown to be an early marker for pathology in various kidney diseases. Other investigators have demonstrated that albuminuria may be an important early marker of kidney disease in children with SCD, with Yee, et al. demonstrating prevalence rates of $20.7 \%$ [20]. In that study, albuminuria correlated with older age and lower hemoglobin concentration but not with low eGFR. Imuetinyan et al. reported an albuminuria prevalence of 20.3\% [30]. Among 90 children with SCD, Becton et al. found albuminuria to be present in 15.5\% [34]. However, it should be noted that albuminuria may regress in some instances. In diabetes, one of the best studied causes of CKD, albuminuria may regress in up to $25 \%$ of patients [35]. It is not known whether this occurs in SCD and the role of albuminuria in predicting progression to end stage renal disease (ESRD) in this patient population remains a valuable area of study.

In addition to albuminuria, multiple investigators are pursuing novel candidate biomarkers that are not currently used in common clinical practice. Urinary levels of renal kallikrein, [36,37] transforming growth factor beta-1 [38], endothelin-1 [39], and KIM-1 and NAG [40] have been, or are currently being investigated, and show promise.

\section{Conclusions}

In conclusion, the results of this retrospective study identified abnormally low eGFR (suggestive of early CKD) in $8 \%$ of patients and elevated blood pressure in $16.6 \%$. These findings highlight the importance of 
performing standardized blood pressure measurements and monitoring serum creatinine and urine albumin excretion on a regular basis in this population. The subset of children with SCD who have low eGFR, hypertension and/or albuminuria may be at particular risk for development of overt sickle cell nephropathy and/or advanced $C K D$ and merit close attention. Our findings highlight the need for a larger prospective longitudinal study aimed at identifying and following children at risk for CKD to determine which factors are predictive of progression. In addition, newer markers of early sickle cell nephropathy (such as novel urine and serum biomarkers, or quantitative MRI) [41] should be explored. A clinical measure that identifies patients in the early stages of sickle cell nephropathy would permit targeted monitoring and treatment to high-risk patients and facilitate clinical trials of new therapies.

\author{
Abbreviations \\ SCD: Sickle cell disease; GFR: Glomerular filtration rate1; CKD: Chronic kidney \\ disease; eGFR: Estimated glomerular filtration rate; HPLC: High performance \\ liquid chromatography; ACS: Acute chest syndrome; MRI: Magnetic \\ resonance imaging; ABPM: Ambulatory blood pressure monitoring; \\ ESRD: End stage renal disease.
}

\section{Competing interests}

The authors have no competing interests to disclose.

\section{Authors' contributions}

PB conceived of the study, participated in its design, performed the background review and performed the cross sectional analysis, and drafted the manuscript. AH participated in manuscript review and design. MAO performed the statistical analysis. JRS helped draft the manuscript. KD conceived of the study, participated in its design, and helped to draft the manuscript. All authors read the final manuscript.

\section{Acknowledgements}

This study was supported in part by the CWRU Nephrology Training Grant (T32-DK 007470) to P.B, and by the Skirball Rainbow Fellowship Award to P.B.

\section{Author details}

${ }^{1}$ Department of Pediatrics, Division of Hematology and Oncology, Akron Children's Hospital, Akron, OH 44302, USA. ²Department of Pediatrics, Case Western Reserve University, Cleveland, OH 44106, USA. ${ }^{3}$ Department of Pediatrics, Rainbow Babies and Children's Hospital, Cleveland, $\mathrm{OH} 44106$, USA. ${ }^{4}$ CWRU Center for the Study of Kidney Disease and Biology, Case Western Reserve University, Cleveland, $\mathrm{OH} 44106$, USA.

Received: 1 June 2013 Accepted: 10 October 2013

Published: 30 October 2013

\section{References}

1. Platt OS, Brambilla DJ, Rosse WF, Milner PF, Castro O, Steinberg MH, Klug PP: Mortality in sickle cell disease. Life expectancy and risk factors for early death. N Engl J Med 1994, 330:1639-1644.

2. Powars DR, Elliott-Mills DD, Chan L, Niland J, Hiti AL, Opas LM, Johnson C: Chronic renal failure in sickle cell disease: risk factors, clinical course, and mortality. Ann Intern Med 1991, 115:614-620.

3. Scheinman J: Sickle cell disease and the kidney. Nat Clin Pract Nephrol 2009, 5:78-88.

4. Saborio P, Scheinman Jl: Sickle cell nephropathy. J Am Soc Nephrol 1999, 10:187-192.

5. Guasch A, Navarrete J, Nass K, Zayas CF: Glomerular involvement in adults with sickle cell hemoglobinopathies: prevalence and clinical correlates of progressive renal failure. J Am Soc Nephrol 2006, 17:2228-2235.
6. Etteldorf JN, Smith JD, Tuttle AH, Diggs LW: Renal hemodynamic studies in adults with sickle cell anemia. Am J Med 1955, 18:243-248.

7. Whitten CF, Younes AA: A comparative study of renal concentrating ability in children with sickle cell anemia and in normal children. J Lab Clin Med 1960, 55:400-415.

8. Oster JR, Lespier LE, Lee SM, Pellogrini EL, Vaamonde CA: Renal acidification in sickle-cell disease. J Lab Clin Med 1976, 88:389-401.

9. Allon M: Renal abnormalities in sickle cell disease. Arch Intern Med 1990, 150:501-504.

10. Osegbe DN: Haematuria and sickle cell disease: a report of 12 cases and review of the literature. Trop Geogr Med 1990, 42:22-27.

11. Wigfall DR, Ware RE, Burchinal MR, Kinney TR, Foreman JW: Prevalence and clinical correlates of glomerulopathy in children with sickle cell disease. J Pediatr 2000, 136:749-753.

12. Ataga $\mathrm{K}$, Orringer $\mathrm{E}$ : Renal abnormalities in sickle cell disease. Am J Hematol 2000, 63:205-211.

13. Tejani A, Phadke K, Adamson O, Nicastri A, Chen CK, Sen D: Renal lesions in sickle cell nephropathy in children. Nephron 1985, 39:352-355.

14. Adams R, McKie V, Nichols F, Carl E, Zhang D, McKie K, Figueroa R, Litaker M, Thompson W, Hess D: The use of transcranial ultrasonography to predict stroke in sickle cell disease. N Engl J Med 1992, 326:605-610.

15. Schwartz GJ, Furth SL: Glomerular filtration rate measurement and estimation in chronic kidney disease. Pediatr Nephrol 2007, 22:1839-1848.

16. Schwartz GJ, Haycock GB, Edelmann CM, Spitzer A: A simple estimate of glomerular filtration rate in children derived from body length and plasma creatinine. Pediatrics 1976, 58:259-263.

17. Schwartz GJ, Muñoz A, Schneider MF, Mak RH, Kaskel F, Warady BA, Furth SL: New equations to estimate GFR in children with CKD. J Am Soc Nephrol 2009, 20:629-637.

18. Staples A, Leblond R, Watkins S, Wong C, Brandt J: Validation of the revised Schwartz estimating equation in a predominantly non-CKD population. Pediatr Nephrol 2010, 25:2321-2326.

19. National High Blood Pressure Education Program (US): The fourth report on the diagnosis, evaluation, and treatment of high blood pressure in children and adolescents, Rev. ed. Bethesda (MD): National Heart, Lung, and Blood Institute (US); 2005:48. NIH publication; no. 05-5267.

20. Yee M, Jabbar SF, Osunkwo I, Clement L, Lane PA, Eckman JR, Guasch A: Chronic kidney disease and albuminuria in children with sickle cell disease. Clin J Am Soc Nephrol 2011, 6:2628-2633.

21. Genovese G, Friedman DJ, Ross MD, Lecordier L, Uzureau P, Freedman BI Bowden DW, Langefeld CD, Oleksyk TK, UscinskiKnob AL, Bernhardy AJ, Hicks PJ, Nelson GW, Vanhollebeke B, Winkler CA, Kopp JB, Pays E, Pollak MR: Association of trypanolytic ApoL1 variants with kidney disease in African Americans. Science 2010, 329:841-845

22. Ashley-Koch AE, Okocha EC, Garrett ME, Soldano K, De Castro LM, Jonassaint JC, Orringer EP, Eckman JR, Telen MJ: MYH9 and APOL1 are both associated with sickle cell disease nephropathy. Br J Haematol 2011, 155:386-394.

23. Aaronson IA, Mann MD: Measurement of glomerular filtration rate in children using technetium-99m diethylenetri- amine penta-acetic acid. S Afr Med J 1985, 67:507-509.

24. Notghi A, Merrick MV, Ferrington C, Anderton JL: A comparison of simplified and standard methods for the measurement of glomerular filtration rate and renal tubular function. Br J Radiol 1986, 59:35-39.

25. Russell CD, Bischoff CG, Rowell KL, Kontzen F, Lloyd LK, Tauxe WN, Dubovsky EV: Quality control of Tc-99m DTPA for measurement of glomerular filtration: concise communication. J Nucl Med 1983, 24:722-727.

26. Perrone RD, Steinman TI, Beck GJ, Skibinsky Cl, Royal HD, Lawlor M, Hunsicker LG: Utility of radioisotopic filtration markers in chronic renal insufficiency: Simultaneous comparison of $125 \mathrm{I}$-lothalamate, $169 \mathrm{Yb}$ DTPA, 99mTc-DTPA, and inulin. The Modification of Diet in Renal Disease Study. Am J Kidney Dis 1990, 16:224-235.

27. Rodman J, Maneval D, Magill L, Sunderland M: Measurement of Tc99m DTPA serum clearance for estimating glomerular filtration rate in children with cancer. Pharmacotherapy 1993, 13:10-16.

28. Rehling M, Moller ML, Thamdrup B, Lund JO, Trap-Jensen J: Simultaneous measurement of renal clearance and plasma clearance of $99 \mathrm{mTc}$ labelled diethylenetriaminepenta-acetate, $51 \mathrm{Cr}$-labelled ethylenediaminetetraacetate and inulin in man. Clin Sci 1984, 66:613-619.

29. Aygun B, Mortier NA, Smeltzer MP, Hankins JS, Ware RE: Glomerular hyperfiltration and albuminuria in children with sickle cell anemia. Pediatr Nephrol 2011, 26:1285-1290. 
30. Imuetinyan BA-I, Okoeguale MI, Egberue GO: Microalbuminuria in children with sickle cell anemia. SJKDT 2011, 22:733-738.

31. Sorof JM, Lai D, Turner J, Poffenbarger T, Portman RJ: Overweight, ethnicity, and the prevalence of hypertension in school-aged children. Pediatrics 2004, 113:475-482.

32. Shatat IF, Jakson SM, Blue AE, Johnson MA, Orak JK, Kalpatthi R: Masked hypertension is prevalent in children with sickle cell disease: a Midwest pediatric nephrology consortium study. Pediatr Nephrol 2012, 28:115-120.

33. Mitsnefes M, Flynn J, Cohn S, Samuels J, Blydt-Hansen T, Saland J, Kimball T, Furth S, Warady B, for the CKiD Study Group: Masked hypertension associates with left ventricular hypertrophy in children with CKD. J Am Soc Nephrol 2010, 21:137-144.

34. Becton LJ, Kalpatthi RV, Rackoff E, Disco D, Orak JK, Jackson SM, Shatat IF: Prevalence and clinical correlates of microalbuminuria in children with sickle cell disease. Pediatr Nephrol 2010, 25:1505-1511.

35. de Boer IH, Rue TC, Cleary PA, Lachin JM, Molitch ME, Steffes MW, Sun W, Zinman B, Brunzell JD, White NH, Danis RP, Davis MD, Hainsworth D, Hubbard LD, Nathan DM: Long-term renal outcomes of patients with type 1 diabetes mellitus and microalbuminuria: an analysis of the diabetes control and complications trial/epidemiology of diabetes interventions and complications cohort. Arch Intern Med 2011, 171:412-420.

36. Schwartz GJ, Lerner NB: The kallikrein-kinin system in sickle cell nephropathy: does it play a role? J Pediatr Hematol Oncol 2006, 28:111-114.

37. Bergmann S, Zheng D, Barredo J, Abboud M, Jaffa A: Renal kallikrein: a risk marker for nephropathy in children with sickle cell disease. $J$ Pediatr Hematol Oncol 2006, 28:147-153.

38. Mohtat D, Thomas R, Du Z, Boakye Y, Moulton T, Driscoll C, Woroniecki R: Urinary transforming growth factor beta-1 as a marker of renal dysfunction in sickle cell disease. Pediatr Nephrol 2011, 26:275-280.

39. Tharaux P, Hagege I, Placier S, Vayssairat M, Kanfer A, Girot R, Dussaule J: Urinary endothelin-1 as a marker of renal damage in sickle cell disease. Nephrol Dial Transplant 2005, 20:2408-2413.

40. Sundaram N, Bennett M, Wilhelm J, Kim M-O, Atweh G, Devarajan P, Malik P: Biomarkers for early detection of sickle nephropathy. Am J Hematol 2011, 86:559-566.

41. Lu L, Sedor JR, Gulani V, Schelling JR, O'Brien A, Flask CA, MacRae Dell K: Use of diffusion tensor MRI to identify early changes in diabetic nephropathy. Am J Nephrol 2011, 34:476-482.

doi:10.1186/1471-2369-14-237

Cite this article as: Bodas et al:: The prevalence of hypertension and abnormal kidney function in children with sickle cell disease -a cross sectional review. BMC Nephrology 2013 14:237.

\section{Submit your next manuscript to BioMed Central and take full advantage of:}

- Convenient online submission

- Thorough peer review

- No space constraints or color figure charges

- Immediate publication on acceptance

- Inclusion in PubMed, CAS, Scopus and Google Scholar

- Research which is freely available for redistribution 